\title{
BIOLUMINESCENT BACTERIA: LUX GENES AS ENVIRONMENTAL BIOSENSORS
}

\author{
Vânia da Silva Nunes-Halldorson ${ }^{1 *}$; Norma Letícia Duran ${ }^{2}$ \\ ${ }^{1}$ Embrapa Pantanal, Corumbá, MS, Brasil; ${ }^{2}$ USDA-ARS US Water Conservation Laboratory, Phoenix, U.S.A.
}

Submitted: March 15, 2002; Returned to authors for corrections: October 18, 2002; Approved: May 06, 2003

\section{MINI-REVIEW}

\begin{abstract}
Bioluminescent bacteria are widespread in natural environments. Over the years, many researchers have been studying the physiology, biochemistry and genetic control of bacterial bioluminescence. These discoveries have revolutionized the area of Environmental Microbiology through the use of luminescent genes as biosensors for environmental studies. This paper will review the chronology of scientific discoveries on bacterial bioluminescence and the current applications of bioluminescence in environmental studies, with special emphasis on the Microtox toxicity bioassay. Also, the general ecological significance of bioluminescence will be addressed.
\end{abstract}

Key words: bacteria, bioluminescence, lux genes, Microtox toxicity bioassay

\section{INTRODUCTION}

Bioluminescent organisms, with their inherent beauty and ease of detection, have always attracted the attention of scientists. Bioluminescent organisms comprise a diverse set of species that are widely distributed, inhabiting terrestrial, freshwater and marine ecosystems (37). A recurring question among researchers in the past has been: What is the biological significance of bioluminescence? The answer to this question, in the case of insects, often focused on the effects of light emission as an attractant in mating. However, when organisms such as bacteria and fungi were brought into the discussion, bioluminescence was often considered vestigial, without any function.

In the last 30 years, however, there has been great progress on the physiology, biochemistry and genetic control of bacterial bioluminescence. Not only have these discoveries revolutionized the area of Environmental Microbiology but have also shed light into areas of ecological, industrial and medical significance. The elucidation of luciferase genes regulation permitted the discovery of intercellular communication among bacteria. This, in turn, has led to a better understanding of bacterial pathogenesis and the associations of microorganisms in the environment. With the advent of molecular biology, it has been possible to construct bioluminescent bacteria that are naturally dark by insertion of $l u x$ genes. This paper illustrates how this has impacted new areas of research and biotechnological applications using luminescent systems as environmental biosensors.

\section{Bioluminescence research}

Bioluminescence is chemiluminescence that requires an enzyme (luciferase). Early studies in the elucidation of the bacterial bioluminescence mechanism (21) suggested that a series of steps would be involved in bioluminescence. Initially, it was proposed that one molecule of reduced flavin mononucleotide $\left(\mathrm{FMNH}_{2}\right)$ was utilized to reduce luciferase. These conclusions were modified a year later, when two reduced flavin molecules instead of one were found to be involved (22). Another research group (36) suggested that during bioluminescence one molecule of $\mathrm{FMNH}_{2}$ combined with oxygen to form a highly reactive organic peroxide while the other combined with an aldehyde molecule to form an aldehyde- $\mathrm{FMNH}_{2}$ compound. These reactions were believed to account for the energetics, but it was difficult to reconcile this with its spectral requirements.

Currently, it is known that the blue-green light emission of bioluminescence, such as that produced by the bacteria

* Corresponding author. Mailing Address: Embrapa Pantanal. Rua 21 de setembro, 1880. Corumbá, MS, Brasil. Telephone: (+5567) 233-2430. Fax: (+5567) 233-1011. E-mail: vania@cpap.embrapa.br 
Photobacterium phosphoreum and Vibrio harvey, arises from the reaction of molecular oxygen with $\mathrm{FMNH}_{2}$ and a long-chain aldehyde to give FMN, water and a corresponding fatty acid. The luciferase enzyme catalyzes a mixed function oxidation of the long-chain aldehyde and $\mathrm{FMNH}_{2}$. The reaction is highly specific for $\mathrm{FMNH}_{2}$, which is protected against autooxidation once bound to the enzyme. The bioluminescent reaction is as follows:

$\mathrm{FMNH}_{2}+\mathrm{O}_{2}+\mathrm{R}-\mathrm{CHO}$ à FMN $+\mathrm{H}_{2} \mathrm{O}+\mathrm{R}-\mathrm{COOH}+\mathrm{Light}(\sim 495 \mathrm{~nm})$

The energy generated is more than sufficient to provide the $60 \mathrm{Kcal} \mathrm{mol}^{-1}$ necessary for light emission (39). This is, however, an energetically costly process. Hastings and Nealson (23) estimated that light emission represents an energy expenditure of approximately six ATP molecules for each photon, assuming $100 \%$ efficiency for the reaction. This explains why energy is conserved in bioluminescent organisms and expressed only when physiologically necessary.

The luciferase enzyme was first purified by McElroy and Green (36). Later, other researchers concluded that the molecular weight of luciferase was within the range of 58 to $76 \mathrm{KDa}(16,28)$. More recent studies have shown that all bacterial luciferases are $\sim 80 \mathrm{KDa}$ heterodimers containing two subunits, $\alpha$ and $\beta$ subunits of approximately 40 and $35 \mathrm{KDa}$, respectively (39). Structurally, the luciferase enzyme is simple and has no metals, nor prosthetic groups or non-amino acid residues. The a subunit appears to dictate the primary kinetic properties, such as substrate binding $\left(\mathrm{FMNH}_{2}\right.$ and aldehyde), light emission and turnover rate (10), while the $\beta$ subunit appears to influence the interaction with flavin and to contribute to an active center (1). However, it has now been demonstrated that purified and immobilized subunits do not exhibit luciferase activity and that activity can be regained if renatured (60), thus suggesting that neither the $\alpha$ nor $\beta$ subunits possess an active center.

Enzyme assays have helped in the elucidation of the bioluminescence mechanism. However, only a few of the simplest reactions are currently understood at the molecular level. The first step in the luminescence reaction pathway involves binding of a single $\mathrm{FMNH}_{2}$ molecule to each luciferase molecule (3), resulting in the formation of the intermediate $\left(\mathrm{EFH}_{2}\right)$. This intermediate reacts with oxygen, resulting in the formation of an unusually stable luciferase-bound flavin hydroperoxide intermediate (EFHOOH) $(20,21,58)$. Next, aldehyde reacts with $\mathrm{EFHOOH}$ to form a flavin-oxygen-aldehyde intermediate, also called a peroxyhemiacetal (E-FOOA) (31). This intermediate has not yet been isolated but it is believed that its lifetime is the rate-limiting step of the reaction. Electrochemical studies suggest that the rate-limiting step involves the transfer of an electron from the dihydroflavin moiety to the weak peroxide bond within the E-FOOA (32), resulting in the cleavage of the $\mathrm{O}-\mathrm{O}$ bond. The intensity of light emission is thus dependent on the amount of E-FOOA and the relative efficiency with which it is converted to the excited state. The excited state is regarded as charge annihilation between two radical-ion centers occurring within constrains of the enzyme pocket. Because the concentrations of aldehyde and long-chain alkyl compounds such as fatty alcohols and amides help stabilize this intermediate (56), the rate of light emission is thus influenced by the solvent conditions.

Bioluminescence in bacteria can also be regulated through a phenomenon known as autoinduction $(12,41,46)$. Autoinduction or quorum sensing was first discovered in Vibrio fischeri, it is cell-to-cell communication that ties gene expression to bacterial cell density. Quorum sensing involves the selfproduction of a diffusible pheromone called an autoinducer (AI), which serves as an extra cellular signal molecule that accumulates in the medium and evokes a characteristic response from cells (42). In bioluminescence, once the concentration of the AI reaches a specific threshold (above $10^{7}$ cells $\mathrm{mL}^{-1}$ ), it triggers the energetically costly synthesis of luciferase and other enzymes involved in luminescence. Thus, by sensing the level of AI, the cells are able to estimate their density and ensure that the luminescent product will be sufficiently high to cause an impact in the environment (64), making the process costeffective. The AI for $V$. fischeri, $\mathrm{N}$-acyl homoserine lactone (AHL), was once thought to be species-specific (23), however recent studies have established that AHL can serve as a signaling molecule for more than 16 genera of gram-negative bacteria. This suggests that the AI protein can facilitate interspecies communication $(18,59)$, allowing quorum-sensing bacteria to monitor the population of other species as well as their own. Quorum sensing is now known to be a widespread regulatory mechanism in bacteria, particularly among a number of pathogens (11), influencing their ecology and associations with eukaryotic organisms.

The $\alpha$ and $\beta$ subunits of luciferase are encoded by the $\operatorname{lux} A$ and $l u x B$ genes, respectively. In Vibrio fischeri, these genes are adjacent in the lux operon, which also contains the genes encoding for the proteins that make up the fatty acid reductase complex for aldehyde synthesis ( $\operatorname{lux} C, D$, and $E$ ) (38). In most luminescent bacteria, the luciferase genes $\operatorname{lu} x A B$ are flanked upstream by $l u x C D$ and downstream by $l u x E$ with transcription from left to right (39). However, Mancini and coworkers (34) found that in P. phosphoreum, the gene luxF is located between $\operatorname{lux} B$ and $\operatorname{luxE}$. Also, the nucleotide sequences of $\operatorname{lux} A$ and luxB genes in $P$. phosphoreum are considerably different from other bacterial luciferases (14).

The regulation of autoinduction in the lux system of $V$. fischeri has been studied in detail $(13,18)$. It is regulated by two genes (luxR and $\operatorname{luxI}$ ), which are present in two divergent operons. The luxI gene is in the rightward operon together with the luxCDABE genes while the luxR is in the leftward operon. The luxI codes for an autoinducer synthase that is responsible 
for the production of the AI. The luxR gene encodes the LuxR protein, which serves as both a receptor for the AI and a transcriptional activator of the lux operon $(12,18)$. Binding of the AI to the LuxR protein forms a complex that acts as a transcriptional regulator, activating transcription from the $l u x$ operon promoter (51). Once induction begins, the level of AI increases rapidly because the gene for AI synthase is part of the lux operon. In this way, the AI controls its own synthesis through a positive feedback circuit (16). Advances in molecular biology have made possible the cloning and expression of the $\operatorname{lux} A B$ genes in bacteria that are normally non-luminescent, transforming them into bioluminescent bacteria. The resulting transformations provide enormous applications $(9,25)$ in industry (53), medicine $(11,35)$, microbial ecology $(6,29)$, and environmental fields (50).

\section{Applications of bioluminescence for environmental microbiology}

Knowledge of the lux gene organization has stimulated the use of bioluminescence genes for the development of wholecell biosensors that have a broad range of environmental applications $(9,50,52)$. These applications include construction of biosensors for detection of contaminants, measurement of pollutant toxicity (44), and monitoring of genetically engineered bacteria released into the environment $(15,33,48)$. Biosensors have also been used as indicators of cellular metabolic activity (57) and for detection of pathogens $(9,53)$. The use and limitations of bioluminescence as reporter systems for pollutants from environmental samples are discussed below.

To date, many bioluminescent reporter bacteria have been genetically engineered by placing a lux gene construct under the control of an inducible promoter (9). The resulting biosensors can be extremely useful in bioremediation studies. Biosensors can be utilized to determine the presence and concentrations of specific pollutants as well as to distinguish between bioavailable forms of pollutants from those that exist in the environment in inert, unavailable forms. For example, Heitzer et al. (24) developed a bioassay to assess the bioavailability of naphthalene and salicylate in contaminated soils. They used the genetically engineered bacterium Pseudomonas fluorescens HK44 carrying the nah-lux reporter plasmid capable of degrading both salicylate and naphthalene $(5,27)$. Similarly, Selifonova et al. (47) constructed a biosensor using fusions of the Tn21 mercury resistance operon (mer) with promoterless luxCDABE from V. fischeri. This mer-lux biosensor demonstrated the semiquantitative detection of inorganic $\mathrm{Hg}$ (II) in natural water in the 0.1 to $200 \mathrm{ppb}$ range and was a good system for distinguishing bioavailable from unavailable forms of mercury.

More recent studies include the use of $E$. coli whole-cell biosensors for detection of linear alkanes and their bioavailability in heating oil-contaminated groundwater samples (54). This was possible through the creation of transcriptional fusion between the alkB promoter of Pseudomonas oleovorans and the promoterless lux $A B$ genes of $V$. harveyi. Another research group constructed a tod-lux fusion and introduced it into Pseudomonas putida $\mathrm{F} 1$. This new strain (TVA8) was used as a whole-cell reporter for benzene, toluene, ethylbenzene, and xylene (BTEX) sensing and bioavailability determination (2). Novel applications for bacterial $\operatorname{lu} x A B$ as reporter genes are still being developed, including the use of recombinant $E$. coli cells containing the stress promoter recA fused to luxCDABE as a biosensor for ionizing radiation (40). In addition, it is possible to use a biosensor to assess changes in effluent toxicity $(8,45)$ rather than monitoring exact toxin concentrations through measurement of bioluminescence quenching. Although new applications for bacterial whole-cell biosensors are expanding, there is growing recognition of their limitations, thereby stimulating the search for new biomarker systems (30).

Some of the limitations of luciferase markers include their dependence on available substrate concentration, physiological state of the bacteria, the poor stability of the luciferase enzyme, and the presence of stimulating or inhibiting factors in the sample to be measured. For example, when the $l u x A B$ genes (wild-type or fused forms) are used to mark cells, the application of an exogenous aldehyde substrate is required for bioluminescence to be observed. This may present a problem since aldehyde can be toxic to cells under prolonged exposure. It is possible to use the entire luxCDABE operon to avoid this dependence on substrate addition. However, this places an added energy burden on the cells and also limits bioluminescence by the amount of aldehyde produced. One method to circumvent this problem has been to isolate the $\operatorname{lux} A B$ from luxCDE by expressing the luxCDE from a plasmid while the $\operatorname{lux} A B$ construct is either chromosomally integrated or present on a compatible plasmid with a low-copy number (9). Therefore, selection of the type of lux gene construct to be used for a particular study must consider factors such as the length of observation time for bioluminescence (minutes, days or months), the type of organisms that will be transformed, and environmental factors. Generally, the wild-type lux genes work well for Gram-negative bacteria while the fuse lux genes work best for Gram-positive bacteria. The latter is essential for luciferase expression under a single promoter in eukaryotic cells (9). Chromosomal integration of the lux genes may be preferred over plasmid-based genes particularly in studies where longterm observations are required. Furthermore, since bioluminescence is dependent on oxygen and cellular energy reserves, this may present problems for studying bacteria in their natural environment because bacterial cells are often starved in nature and anaerobic conditions may prevail in certain environments.

The inherent limitation of bacterial luciferase enzymes has prompted attention to other bioluminescence systems such as 
the green fluorescent protein (GFP) of the jellyfish Aequorea victoria $(55,65)$. Some advantages of the GFP fluorescent protein are that it is very stable, does not require the addition of an aldehyde substrate and is more efficient and less energy costly than bacterial luciferases. The stability of the GFP protein can be both an advantage and disadvantage for environmental studies. It permits the detection of organisms found under starved conditions or in a viable-but-nonculturable state but can also detect tagged cells regardless of their viability (30). In spite of the limitations associated with bacterial bioluminescent systems, their usefulness as biosensors in laboratory and field conditions have been proven. This is particularly true in bioassays where environmental conditions can be controlled such as in the Microtox toxicity bioassay. The next section will describe how this system functions.

\section{The microtox system}

Commonly used toxicity assays that employed fish or Daphnia, as test organisms are time-consuming and expensive. Thus, microbial bioassays are increasing in popularity for toxicity measurement of environmental pollutants on living organisms. Microbial bioassays offer a rapid response, low cost, and improved reproducibility. In the last 18 years, the Microtox system has been used by several agencies to assess the impact of chemicals in the environment $(8,9)$. This is a commercially available toxicity bioassay that uses the naturally bioluminescent bacteria, Photobacterium phosphoreum, and more recently, Vibrio fischeri (43). Light emission in P. phosphoreum depends on functional metabolism. Consequently, toxic agents that affect the metabolism or compromise bacterial viability cause a reduction in light output that is proportional to the toxicity of the sample. The results are expressed as effective concentration $\left(\mathrm{EC}_{50}\right)$ values at which there is a $50 \%$ decrease in light emission.

The physiological effects of iron, oxygen and osmolarity on luminescence are only partially understood but can affect the accuracy of the bioassay $(17,53)$. The effects of endogenous aldehyde and internal ions on bioluminescence expression of $P$. phosphoreum have been well documented $(26,56,61)$. Watanabe et al. (61) reported that luminescence in $P$. phosphoreum is affected by endogenous aldehyde and potassium ion concentrations. They believed that an increase in the concentration of intracellular $\mathrm{K}^{+}$favored the transcription of luminescence genes (lux operon) due to conformational changes in bacterial chromosomes thereby increasing the expression of genes involved in aldehyde synthesis. Hence, the testing medium used in the Microtox assay has been formulated to contain potassium, calcium and magnesium ions. Sodium chloride is another external factor that affects the light intensity in $P$. phosphoreum and must therefore be carefully regulated in the bioassay. Because P. phosphoreum and V. fischeri are marine organisms, the addition of $\mathrm{NaCl}$ to the test solution to reach saline concentration of approximately $20 \mathrm{~g} / \mathrm{L}$ is recommended.
Salt concentrations below $5 \mathrm{~g} / \mathrm{L}$ can cause the cell membranes of $P$. phosphoreum to rupture due to low external osmotic pressure. The $\mathrm{pH}$ and temperature can also affect the bioassay results and require careful control; the recommended ranges are 6.5-7.0 and $10-25^{\circ} \mathrm{C}$, respectively. It has been reported that factors relating to cell density can have an effect on bioluminescence (61); we now know this to be the effects of autoinduction. Therefore, it is recommended that fresh bacterial suspensions are used and that cell density is controlled (45).

When experimental conditions are appropriate, the Microtox bioassay can have equal or greater precision than the traditional fish and Daphnia bioassays. Microtox is a simple bioassay that has several advantages over other toxicity tests. One of the advantages is its good statistical significance since the observed response is produced by a large number of cells ( $10^{6}$ ). Also, this bioassay is amenable to automated toxicity data collection that can be used in mathematical models, such as Quantitative Structure-Activity Relationships (45). Because of its rapid response and excellent sensitivity, the Microtox system is currently being used for toxicity assays in complex environmental media. For example, it has been used for the assessment of toxicity in remediated soil from a contaminated site with various pesticides and their major metabolites (19). The Microtox system has also been used to evaluate the effectiveness of toxicity reduction during wastewater treatment (63) and for initial screening of cyanobacteria blooms (7). Other potential uses of this system are within the Offshore Oil and Gas Industry to monitor discharges from offshore installations at source (62). As more agencies and researchers explore the use of the Microtox bioassay in their field of work, there will be an increase in the potential applications of this equipment for environmental studies.

\section{The ecological significance of bioluminescence}

The function of light emission in higher organisms usually falls under 3 categories: To assist in predation (offense), to aid in avoiding predators (defense) and for intraspecies communication such as courtship. While the functions of luminescence are quite clear for higher organisms, the ecological significance of bacterial and fungal luminescence is less straightforward. Bacterial bioluminescence predominates in marine ecosystems, particularly among fish (49). Studies of marine bioluminescence have provided great understanding on symbiotic relationships particularly from the Euprymna scolopes-V. fischeri mutualism (4). The squid has specialized organs in which the luminous bacteria grow and provides behaviorally useful light that help attract pray to the squid. Upon bacterial colonization, these specialized organs undergo developmental changes that would not take place in the absence of the bacteria. Once the relationship has been established, the squid maintains an acceptable population of the symbiont by expelling $90 \%$ of the bacteria population every morning. The expelled bacteria are viable and regrow flagella. In 
this manner, bacteria are given room and board and helped in their dissemination so that both organisms benefit from the association.

However, the ecological significance of bioluminescence for non-symbiotic bacteria such as $V$. harveyi is more difficult to explain. $V$. harveyi is a free-living marine enterobacteria. It is found in the gut of fishes and invertebrates and is shed in fecal matter. It is believed that by helping to attract organisms to ingest fecal pellets, these bacteria play an important role in water column turnover. Both organisms benefit from this interaction; the fish consume nutrients that otherwise would be lost to the ocean floor and the bacteria find themselves in the gut, a more nutrient-rich environment, where they can proliferate, be excreted, and continue the cycle. Hence, it appears that bioluminescence in $V$. harveyi serves only the purpose of dispersion and propagation (64). Furthermore, not all free-living bioluminescent bacteria are limited to the fecalgut cycles. Some luminous bacteria are able to exploit habitats where there is no apparent positive selection for the ability to emit light. The habitat may merely serve as a confined situation allowing bacterial growth and the accumulation of an AI necessary for light production. Therefore, autoinduction has been regarded as a mechanism that allows for physiological adaptation to alternate environments.

Overall, bioluminescence has helped us understand the intricacies of microbial ecology. It has led to significant discoveries on how bacteria interact with higher organisms and among themselves. This has permitted the understanding of symbiotic associations and the discovery of bacteria communication. The latter offers promise in understanding how disease-causing bacteria colonize and infect humans and may provide future biological control methods for pathogens (11). Undoubtedly, there are still many questions regarding the ecology and biological significance of luminous bacteria. As new information on the biochemistry, physiology and distribution of luminous bacteria develops, so will the possibilities for exploiting bioluminescent systems and their biotechnological applications.

\section{RESUMO}

\section{Bactérias bioluminescentes: os genes $l u x$ como biosensores ambientais}

Bactérias que emitem bioluminescência são amplamente distribuídas em ambientes naturais. Ao longo dos anos vários pesquisadores vêm estudando a fisiologia, bioquímica e controle genético da bioluminescência. Essas descobertas têm revolucionado a Área de Microbiologia Ambiental através da utilização dos genes lux como biosensores em estudos ambientais. Esta revisão examinará a cronologia de descobertas científicas da bioluminescência bacteriana e as aplicações atuais em estudos ambientais, salientando a utilização do teste de toxicidade Microtox. A significância ecológica da bioluminescência será também examinada.

Palavras-chave: bactéria, bioluminescência, genes lux, teste de toxicidade Microtox

\section{REFERENCES}

1. Anderson, C.; Tu, S.C.; Hastings, J.W. Subunit exchange between and specific activities of mutant bacterial luciferases. Biochem. Bioph. Res. Com., 95: 1180-1186, 1980.

2. Applegate, B.M.; Kehrmeyer, S.R.; Sayler, G.S. A chromosomally based tod-luxCDABE whole-cell reporter for benzyne, toluene, ethybenzene, and xylene (BTEX) sensing. Appl. Environ. Microbiol., 64: 2730-2735, 1998.

3. Becvar, J.E.; Hastings, J.W. Bacterial luciferase requires one reduced flavin for light emission. Proc. Nat. Acad. Sci., 72: 3374-3376, 1975 .

4. Boettcher, K.J.; Ruby, E.G. Depressed light emission by symbiotic Vibrio fischeri of the Sepiolid Squid Euprymna scolopes. J. Bacteriol., 172: 3701-3706, 1990 .

5. Burlage, R.S.; Gary S.S.; Larimer, F. Monitoring of naphthalene catabolism by bioluminescence with nah-lux transcriptional fusions. J. Bacteriol., 172: 4749-4757, 1990.

6. Burlage, S.E.; Kuo, C.T. Living biosensors for the management and manipulation of microbial consortia. Ann. Rev. Microbiol., 48: 291309, 1994

7. Campbel, D.L.; Lawton, L.A.; Beattie, K.A.; Codd, G.A. Comparative assessment of the specificity of the brine shrimp and microtox assays to hepatotoxic (Mycrocystin-LR-Containing) Cyanobacteria. Environ. Toxicol. Water Qual., 9(1): 71-77, 1994.

8. Chang, J.C.; Taylor, A.B.; Leach, F.R. Use of the Microtox assay system for environmental samples. Bull. Environm. Contam. Toxicol., 26: $150-156,1981$.

9. Chatterjee, J.; Meighen, E.A. Biotechnical applications of bacterial bioluminescence (lux) genes. Photochem. Photobiol., 62: 641-650, 1995.

10. Cline, T.W.; Hastings, J.W. Mutationally altered bacterial luciferase:implications for subunit functions. Biochem., 11: 3359 $3370,1972$.

11. de Kievit, T.R.; Iglewski, B.H. Bacterial quorum sensing in pathogenic relationships. Infec. Immun., 68: 4839-4849, 2000.

12. Eberhard, A. Inhibition and activation of bacterial luciferase synthesis. J. Bacteriol., 109: 1101-1105, 1972.

13. Engebrecht, J.; Nealson, K.H.; Silverman, M. Bacterial bioluminescence: Isolation and genetic analysis of function from Vibrio fischeri. Cell, 32: 773-781, 1983.

14. Ferri, S.R.; Soly, R.R.; Szittner, R.B.; Meighen, E.A. Structure and properties of luciferase from Photobacterium phosphoreum. Biochem. Bioph. Res. Com., 176: 541-548, 1991.

15. Flemming, C.A.; Lee, H.; Trevors, J.T. Bioluminescent mostprobable-number method to enumerate lux-marked Pseudomonas aeruginosa UG2Lr in soil. Appl. Environ. Microbiol., 60: 34583461,1994

16. Friedland, J.; Hastings, J.W. Nonidentical subunits of bacterial luciferase: Their isolation and recombination to form active enzyme. Proc. Nat. Acad. Sci., 58:2336-2342, 1957.

17. Friedrich, W.F.; Greenberg, E.P. Glucose repression of luminescence and luciferase in Vibrio fischeri. Arch. Microbiol., 134: 87-91, 1983.

18. Fuqua, C.; Winanas, S.C.; Greenberg, E.P. Census and consensus in bacterial ecosystems: the LuxR-LuxI family of quorum-sensing transcriptional regulators. Annu. Rev. Microbiol., 50: 727-751, 1996.

19. Galli , R.; Munz, C.D.; Scholtz, R. Evaluation and application of aquatic toxicity test: use of the microtox test for the prediction of toxicity based upon concentrations of contaminants in soil. Hydrobiol. 273: 179-189, 1994 
20. Hastings, J.W.; Balny, C.; Le Peuch C.; Douzou, P. Spectral properties of an oxygenated luciferase-flavin intermediate isolated by lowtemperature chromatography. Proc. Nat. Acad. Sci., 70: 3468-3472, 1973.

21. Hastings, J.W.; Gibson, Q.H. Intermediates in the bioluminescent oxidation of reduced flavin mononucleotide. J. Biol. Chem., 238: 2537-2554, 1963.

22. Hastings, J.W.; Gibson, Q.H.; Greenwood, C. On the molecular mechanism of bioluminescence. I. The role of long-chain aldehyde. Proc. Nat. Acad. Sci., 52: 1529-1535. 1964.

23. Hastings, J.W.; Nealson, K.H. The symbiotic luminous bacteria. In: Starr, M.P.; Stolp, H.; Truper, H.G.; Balows, A.; Schkegel, H.G. (eds.) Prokaryotes:A handbook of habitats, isolation and identification bacteria. Springer-Verlag, New York, 1981, p. 1332-1345.

24. Heitzer, A.; Webb, O.F.; Thonnard, J.E.; Slayler, G.S. Specific and quantitative assessment of naphthalene and salicylate bioavailability by using a bioluminescent catabolic reporter bacterium. Appl. Environ. Microbiol., 58: 1839-1846, 1992.

25. Hill, P.J.; Rees, C.E.D.; Winson, M.K.; Stewart, G.S.A.B. The application of lux genes. Biotechnol. Appl. Biochem., 17: 3-14, 1993.

26. Kempner, E.S.; Hanson, F.E. Apects of light production by Photobacterium fischeri. J. Bacteriol., 95: 975-979, 1968.

27. King, J.M.H.; DiGrazia, P.M.; Applegate, B.; Burlage, R.; Sanseverino, J.; Dunbar, P.; Larimer, F.; Sayler, G.S. Rapid, sensitive bioluminescent reporter technology for naphthalene exposure and biodegradation. Science, 249: 778-781, 1990.

28. Kuwabara, S.; Cormier, M.J.; Dure, L.S.; Kreiss, P.; Pfunderer, P. Crystalline bacterial luciferase from Photobacterium fischeri. Proc. Nat. Acad. Sci., 53: 822-828, 1965.

29. Lindow, S.E. The use of reporter genes in the study of microbial ecology. Mol. Ecol., 4: 555-566, 1995.

30. Lowder, M.; Unge, A.; Maraha, N.; Jansson, J.K.; Swiggett, J.; Oliver, J.D. Effects of starvation on the viable-but-nonculturable state on green fluorescent protein (GFP) fluorescence in GFP-tagged Pseudomonas fluorescens A506. Appl. Environ. Microbiol., 66: 3160-3165, 2000.

31. Macheroux, P.; Ghisla, S.; Hastings, J.W. Spectral detection of an intermediate preceding the excited state in the bacterial luciferase reaction. Biochem., 32: 14183-14186, 1993.

32. Mager, I.X.; Tu, S.C. Chemical aspects of bioluminescence. Photochem. Photobiol., 62: 607-614, 1995.

33. Mahaffee, W.F.; Bauske, E.M.; van Buurde, J.W.L.; van der Wolf, J.M.; van den Brink, M.; Kloepper, J.W. Comparative analysis of antibiotic resistance, immunofluorescent colony staining, and a transgenic marker (bioluminescence) for monitoring the environmental fate of a rhizobacterium. Appl. Environ. Microbiol., 63: 1617-1622, 1997.

34. Mancini, J.; Boylan, M.; Soly, R.; Ferri, S.; Szittner, R.; Meighen, E. Organization of the lux genes of Photobacterium phosphoreum. J. Biolum. Chemiolum., 3: 201-205, 1989.

35. Masuda-Nishimura, I.; Fukuda, S.; Sano, A.; Kasai, K.; Tatsumi, H. Development of a rapid positive/absent test for coliforms using sensitive bioluminescence assay. Lett. Appl. Microbiol., 30: 130135, 2000.

36. McElroy, W.D.; Green, A.A. Enzymatic properties of bacterial luciferase. Arch. Biochem. Biophys., 56: 240-255, 1955.

37. Meighen, E.A. Molecular biology of bacterial bioluminescence Microbiol. Rev., 55: 123-142, 1991.

38. Meighen, E. Genetics of bacterial bioluminescence. Annu. Rev. Genet., 28: 117-139, 1994.

39. Meighen, E.; Dunlap, P.V. Physiological, biochemical and genetic control of bacterial luminscence. Adv. Microb. Physiol., 34: 1-67, 1993.

40. Min, J.; Lee, C.W.; Moon, S.-H.; LaRossa, R.A.; Gu, M.B. Detection of radiation effects using recombinant bioluminescent Escherichia coli strains. Rad. Environ. Bioph., 39: 41-45, 2000.

41. Nealson, K.H. Autoinduction of bacterial luciferase. Ocurrence, Mechanism and Significance. Arch. Microbiol., 112: 73-79, 1977.

42. Nealson, K.H.; Platt, T.; Hastings, J.W. Cellular control of the synthesis and activity of the bacterial luminescent system. J. Bacteriol., 104: 313-322, 1970.
43. Pardos, M.; Benninghoff, C.; Thomas, R.L.; Khim-Heang, S. Confirmation of elemental sulfur toxicity in the Microtox assay during organic extracts assessment of freshwater sediments. Environ. Toxicol. Chem., 18(2): 188-193, 1998.

44. Pittsyn, L.R.; Horneck, G.; Komova, O.; Kozubek, S.; Krasavin, E.A.; Bonev, M.; Rettberg, P. A biosensor for environmental genotoxin screening based on SOS lux assay in recombinant Escherichia coli cells. Appl. Environ. Microbiol., 63: 4377-4384, 1997.

45. Ribo, J.M.; Kaiser, K.L.E. Photobacterium phosphoreum toxicity bioassay. I. Test procedures and applications. Tox. Ass. Internat. Quart., 2: 305-323, 1987.

46. Rossom, R.A.; Nealson, K.H. Autoinduction of bacterial bioluminescence in a carbon limited chemostat. Arch. Microbiol., 129: 299-304, 1981.

47. Selifonova, O.; Burlage, R.; Barkay, T. Bioluminsecent sensors for detection of bioavailable $\mathrm{Hg}(\mathrm{II})$ in the environment. Appl. Environ. Microbiol., 59: 3083-3090, 1993.

48. Shaw, J.J.; Dane, F.; Geiger, D.; Kloepper, J.W. Use of bioluminescence for detection of genetically engineered microorganisms released into the environment. Appl. Environ. Microbiol., 58: 267-273, 1992.

49. Silverman, M.; Martin, M.; Engebrecht, J. Regulation of luminescence in marine bacteria. In: Hopwood, D.; Chater, K.F. (eds.). Genetics of bacteria diversity. Academic Press, New York, 1989, p. 71-85.

50. Steinberg, S.M. A review of environmental applications of bioluminescence measurements. Chemosphere, 30: 2155-2197. 1995.

51. Stevens, A.M.; Greenberg, E.P. Quorum sensing in Vibrio fischeri: essential elements for activation of the luminescence genes. $J$. Bacteriol., 179: 557-562. 1997.

52. Stewart, G.S.A.B. Biosensors. Lancet, 341: 945-953, 1993

53. Stewart, G.S.A.G.; Denyer, S.P.; Lewington, J. Microbiology illuminated: gene engineering and bioluminescence. Trends Food Sci. Technol. Tod., 2: 19-22, 1991.

54. Sticher, P.; Jaspers, M.C.M.; Stemmler, K.; Harms, H.; Zehnder, A.J.B.; van der Meer, J.R. Development and characterization of a whole-cell bioluminescent sensor for bioavailable middle-chain alkanes in contaminated groundwater samples. Appl. Environ. Microbiol., 63: 4053-4060, 1997.

55. Tsien, R.Y. The green fluorescent protein. Annu. Rev. Biochem., 67: 509-544, 1998.

56. Tu, S.C. Isolation and properties of bacterial luciferase oxygenated flavin intermediate complexed with long-chain alcohols. Biochem., 18: 5940-5945, 1979.

57. Unge, A.; Tombolini, R.; Molbak, L.; Jansson, J.K. Simultaneous monitoring of cell number and metabolic activity of specific bacterial populations with a dula $g f p-\operatorname{lux} A B$ marker system. Appl. Environ. Microbiol., 65: 813-821, 1999.

58. Vervoort, J.; Muller, F.; Lee, J.; van den Berg, W.A.M.; Mooflen, C.T.W. Identification of the true carbon-13 nuclear magnetic resonance spectrum of the stable intermediate II in bacterial luciferase. Biochem., 25: 8062-67, 1986.

59. von Bodman, S.B.; Majerczak, D.R.; Coplin, D.L. A negative regulator mediates quorum-sensing control of exopolysaccharide production in Pantoea stewartii subsp. stewartii. Proc. Natl. Acad. Sci., 95: 7687-7692, 1998.

60. Watanabe, H.; Hastings, J.W.; Tu, S.C. Activity and subunit functions of immobilized bacterial luciferase. Arch. Bioch. Byophy., 215: 405413, 1982.

61. Watanabe, H.; Humio, I.; Woodland Hastings, J. Effects of aldehyde and internal ions on bioluminescence expression of Photobacterium phosphoreum. Arch. Microbiol., 156: 1-4, 1991.

62. Whale, G.F. Potential applications of the microtox toxicity test within the offshore oil and gas industry. Conf. Health Saf. Environ. Oil Gas Explor. Product., Jakarta, Indonesia, 1994.

63. Whelan, M.P.; Tansel, B.; Parker, G.N. Effectiveness of toxicity reduction during wastewater treatment. Proc. Amer. Soc. Civil. Eng., Boca Raton, Florida, 1992.

64. Wilson, T.; Hastings, J.W. Bioluminescence. Annu. Rev. Cell Dev. Biol., 14: 197-230, 1998.

65. Yang, F.; Moss, L.G.; Phillips, G.N. The molecular structure of green fluorescent protein. Nat. Biotechnol., 14: 1246-1251, 1996. 